\title{
Attitudes of Secondary School Students towards Outdoor Games: A Scale Development Study
}

\author{
Emine A. Baysal ${ }^{1 *}$, ijlal Ocak ${ }^{2}$, Kübra Öztürk ${ }^{3}$ \\ ${ }^{1}$ Assistant Professor, Afyon Kocatepe University/Sandıklı School of Applied Sciences, Turkey \\ ${ }^{2}$ Professor, Afyon Kocatepe University/Faculty of Education, Turkey \\ ${ }^{3}$ Teacher, 05446605781, Afyon Kocatepe University/Faculty of Eucation, Turkey
}

\begin{abstract}
The aim of this study was to develop a reliable and viable scale to determine secondary school students' attitudes towards outdoor games. During development process, firstly, relevant area was scanned and key expressions that would prepare theoretical ground were determined. Based on these key expressions, eleven open-ended questions were prepared and applied to a group of eighty students. In line with data obtained, a 5-point Likert type scale pre-trial form consisting of sixty-four items was created. The pre-trial form was applied to a total of 254 secondary school students in Afyonkarahisar and Uşak. Both exploratory and confirmatory factor analysis were used for factor structure. According to analyzes, The Secondary School Students' Outdoor Games Attitude Scale consists of three sub-dimensions and twenty-nine items. It was seen that factor loads of items were between .776 and .510 . It was determined as $54 \%$ of variance value for whole scale. CFA result were calculated as $\chi^{2}=851$, RMSEA $=0.0709 ;$ SRMR $=0.0509 ; \mathrm{CFI}=0.881$ and TLI $=0.871$. Cronbach's Alpha coefficient was calculated as .95 . In addition, test-retest application was carried out with thirty participants. There was a thirty-day time difference between the first and second applications. Correlation coefficients between factors was found to be significant. According to the analyzes performed, validity and reliability of scale were ensured. The scale was named as "The Secondary School Students' Attitude Scale towards Outdoor Games".
\end{abstract}

Keywords: attitute, Game, Outdoor.

\section{INTRODUCTION}

Children have got to know their environment and themselves with the help of movement since they have been born. While they cannot perform some physical activities such as walking and speaking or they have not reached a certain mental maturity, they make their first interaction with their environment through their senses. This situation continues in early childhood as well. On one hand children interact with environment, on the other hand they contribute to their physical, cognitive, emotional, behavioral, social and language development by including activities such as sports, games and entertainment in daily life activities (Çavuşoğlu, 2013; Süslü, 2014). The most entertaining one is undoubtedly game among these activities. Famous educators such as Montessori, Piaget, Rousseou and Frobel associated these active activities of children with their behaviors and emphasized the contribution of games to the development of individuals (Bilton, 2010; Ouvry, 2003). According to Miller and Kuhaneck (2008), games are children's primary and most important occupations that prepare them for future. Huizinga (2017) emphasized that games are free time activities that increase intrinsic motivation of individuals. Games are activities that prepare children for future with their cognitive development, develop their creativity, problem-solving skills and sense of freedom (Mclnnes \& Birdsey, 2013). They allow individuals both to interact with environment and to communicate and to make progress in various areas of development.
Games are the most natural, most frequently used and healthiest way to communicate. In any case, a game, in which children take part willingly and with pleasure, is based on their physical, cognitive, language development, emotional and social development. It is a part of real life and expressed as the most effective learning process for children (Dönmez Baykoç, 1992). Playing games is the best educational activity for children in social, physical and conceptual development. They learn to control their environment, the feeling of competition and fun by communicating with other children by using various game materials. Playing games is a way for children to acquire basic knowledge of the world. This information paves the way for all sciences related to language, art, social sciences, mathematics and science that they will

\section{Corresponding Author e-mail: akkasemine85@hotmail.com} https://orcid.org/0000-0002-5711-0847

How to cite this article: Baysal EA, Ocak I, Öztürk K (2022). Attitudes of Secondary School Students towards Outdoor Games: A Scale Development Study. Pegem Journal of Education and Instruction, Vol. 12, No. 1, 2022, 115-130

Source of support: Nil

Conflict of interest: None.

DOI: $10.47750 /$ pegegog.12.01.11

Received: 19.08 .2021

Accepted: 22.11.2021 Publication: 01.01.2022 
learn later (Korkmaz, 2009). While playing with friends, children learn basic rules such as sharing, helping, establishing positive relations with environment, respecting the rights of others and taking responsibility. Playing games requiring physical power such as jumping, running, jumping, climbing and crawling not only ensure regular functioning of systems such as circulation, respiration, digestion and excretion, but also increase oxygen intake, blood circulation and transport of nutrients to tissues. Moreover, children can reflect some situations that disturb them in real life, share feelings that they cannot share with others and express them through games (Arnas, 2007). In short, games are activities that improve individuals in many ways.

Outdoor games are one of the other types of games just like as imitation games, creative games, adventure games, building games and mind games. In this type of games, children have opportunity to explore, create, build, destroy, learn how to use some objects in an open area. In addition, they gain concrete experiences with their senses in natural environment and have opportunity to get to know life (Demiriz, Karadağ \& Ulutaş, 2003). In outdoor games, children find answers to their emotional needs by gaining many experiences such as planning, waiting in line, sharing, talking with teacher and other children, establishing relationships and socializing (Oğuzkan \& Oral, 1997). Outdoor games contribute to equipping children with some important features such as social competence, problem solving, creative thinking and safety skills that they will need when they become adults (Rivkin, 2000). Children playing outdoors not only develop a positive attitude towards environment, but also grow emotionally and academically by participating in creative games, developing initiative, investigating properties of objects or what they see in their environment. They understand basic academic concepts such as how to use simple tools (Singer \& Singer, 2000). Outdoor games also allow children to explore society they live in, enjoy sensory experiences related to dirt, water, sand and mud; collect various objects they find in nature; develop various hobbies and increase their interest in physical activities (Kalish, 1995).

According to Godbey (2009), Mackett and Paskins (2008) and Scales (1987), when children play in outdoor, they do much more than spending energy. Outdoor plays make that human health is vast and growing. They focus in a very specific way, often replay their actions and steps in game. Children mostly produce games themselves since outdoor venues are generally not thematic. Children are constantly in search of creating fun among themselves in outdoor. Flexibility in games gives children opportunity to express themselves in a way that comes from their own cultural perspective and their own world. Contrary to indoor games, outdoor games that can be played with less explanation. They allow children to interpret and reveal their own abilities. The materials of outdoor games and the properties of these objects can be adapted to many other outdoor games. This situation enables children to motivate in outdoor games for a longer period of time (Perry, 2001). In addition, Trawick-Smith (1998) emphasized that outdoor games are much more persuasive and less demanding than indoor games. The confusion or chaos rising in outdoor games is resolved without much discussion.

Outdoor games, by their nature, involve real game movements such as running, chasing, wrestling or jumping, rather than games that require pretending. Pellegrini and Smith (1998) described this as both a primitive expression of emotions and playful fun. Perry (2001), on the other hand, expressed it as reflecting complex emotions that are difficult to do with pretend games or indoor games, and promoting social development. Outdoor games can improve mental, physical and emotional health of individuals; enable individuals to be creative, focused and emotionally connected to natural world. Individuals' involvement in outdoor games with their peers can prevent social chaos that may arise and even prevent its re-emergence. Andre (2019) emphasized that many people are prejudiced against outdoor games and avoid outdoor games. They generally see themselves as lacking in skill or worrying about getting lost, injured or encountering wild animals in outdoor. However, outdoor games enable individuals to develop their feelings of discovery, self-confidence and skills.

In order for children to act like scientists, that is, to understand and make sense of events, they need to see, touch, smell, hear, practice, wonder and find solutions to problems; take place in the outside world (Türkmen, 2010). Children involved in outdoor games support their learning and develop compulsory skills such as imagination, communication and problem solving by participating in activities such as group work, solving puzzles, daydreaming and discovery activities. They can also create imaginary worlds through stories in games (Broström, 1997; Early Childhood Education Forum, 1998; Hope 2008). This situation enables children to express themselves and gives them a sense of independence, selforganization, participation, empowerment and peace (White, 2011). Outdoor games offer children freedom to explore, to be physically active and enthusiastic. These types of games, whether they are an extension of children's experiences in indoor environments or new experiences, offer different alternatives compared to indoors. Children can move around in a larger area, be more energetic and noisy and feel free from dirt and spills. This allows them to get rid of constraints required by learning paths (Waite, 2011).

According to Vygotsky (1978), children have fascinating spirit of proximal development in outdoor games. In fact, to make it clear, in outdoor games, children can move freely, struggle with difficult activities, know that they can ask for help when things get more difficult and they can move much more comfortably and confidently. In outdoor games, there is 
no situation such as being controlled by others, which is usually encountered in indoor games. Individuals can support and help children (Bilton, 2010). In this case, children experience outdoor exploration more independently. They ensure their development through movement, which is the most natural channel of their own experience (Ouvry, 2003; Baldock, 2011). Waite (2011) stated that children's learning by experience appeals to their multiple senses and thus prevents learning difficulties. In this case, students with special educational needs can also benefit from outdoor games. Through experiential learning, children can find opportunity to support their learning styles and schemas (Athey, 1990).

Similar playgrounds can be created for children and comprehensive participation of students can be ensured in games organized in indoor. However, the fact that these environments are highly structured and require constant guidance or direction in process prevents the flexibility of learning environments. Outdoor games affect both quantity and quality of situations that children need to learn and especially increase interaction between social groups. In many studies (Hart \& Risley, 1995; Natriello et al., 1990; Huttenlocher et al., 1991; Jencks \& Phillips, 1998), the inadequacies of children in social groups, especially those from a disadvantaged background, who did not receive pre-school education and have a very limited vocabulary, are tried to be minimized with such games.

Handler and Epstein (2010) emphasized that games played in outdoor and structured with a certain curriculum affect physical development, intellectual development, social and emotional development of individuals positively. According to The White House Presidential Memorandum: Establishing a Task Force on Childhood Obesity (2010), one in five children is overweight or obese by their sixth birthday. Physical inactivity as well as malnutrition have caused to a $100 \%$ increase in childhood obesity in the United States since 1980 (Sanders, 2002). Unfortunately, this situation is similar in our country. When parents' fear of letting their children play outside is added to this and they do not see outside as an exciting environment for play, it is highly likely that there are more sedentary children (Handler \& Epstein, 2010). At this point, outdoor games that can be included in curricula can be an alternative to prevent such negative sides. Linn (2010) showed that efforts to limit children's media exposure make children play more creatively in green areas.

Outdoor games are extremely important activities for individuals' self-development and self-awareness. For example, in a study conducted in England, it was concluded that after participating in outdoor programs, most of the individuals' self-confidence level and their ability to act independently increased and they began to look at the outside world and their individual lives from a much more realistic perspective (Hopkins \& Putnam, 2012). From this point of view, when long-term effects on individuals are taken into account, importance of outdoor games becomes even more remarkable. Both individuals' improvement and the experience of working collaboratively in a group dynamic will strengthen their social relations. In addition to this, increasing their participations, gaining leadership qualifications, being successful in case of stress and having risk management will contribute to their individual skills. With outdoor games, individuals will learn to trust themselves and improve their decision-making skills. For this reason, involvement of outdoor games in learning environments will enrich that environment and make it possible for individuals to gain experience. From this point of view, it is vital to know students' attitudes towards outdoor games. However, there is not a scale on the secandory school students'attitudes towards outdoor games. This kind of scale can fill the blank in field. In this context it was aimed to develop a valid and reliable scale to determine the attitudes of secondary school students towards outdoor games.

\section{Method}

\section{Research Design}

In the study, sequential explanatory design, one of mixed research methods, was used in order to develop the Secondary School Students' Attitude Scale towards Outdoor Games. In this design, firstly qualitative data was collected and analyzed. Then quantitative data were collected and analyzed (Tashakkori \& Teddlie, 2003; Creswell, 2005). Creswell (2005) stated that this design also allows the development of a standardized data collection tool. In this study, first of all, a literature review was carried out, and then the views of students obtained from open-ended questions were analyzed. Findings obtained by evaluating answers to questions were used as a source for creation of scale items in item pool. In the second step, data obtained from draft scale were analyzed and validity, reliability, test-retest analyzes of scale were made.

\section{Participants}

The trial applications of the Secondary School Students' Attitude Scale towards Outdoor Games were carried out in the 2020-2021 academic year. The participants of study was determined by typical case sampling method, one of purposeful sampling methods. Typical situations are situations that contain information explaining generally studied event or phenomenon among many similar ones in universe (Patton, 2005). For this reason, study group of research consists of 254 students studying in the 5th, 6th, 7th and 8th grades of secondary schools in Uşak and Afyonkarahisar. It is thought that study group is a group having ability to represent the universe and does not differ from the universe in terms of its basic characteristics. In addition, in factor analysis studies by Comrey and Lee (1992), Cornish (2006) and Child (2006), 
the sample size was expressed as " 50 " very bad, " 100 ” bad, "200" moderate, “300" good, " 500 ” very good and " 1000 and more" excellent. In this context, 254 samples were considered sufficient for a 64 -item trial scale. After validity and reliability analyzes of draft scale were completed, a test-retest application was carried out with a group of 30 participants. Demographic information of the students is given in Table 1:

Table 1 includes characteristics of study group of study. 152 (59.8\%) female and 102 (40.2\%) male students participated in study. 54 (21.3\%) of students are in fifth grade, 81 (31.9\%) are in sixth grade, $64(25.2 \%)$ are in seventh grade and $55(21.7 \%)$ are in eighth grade. This situation shows that students from different levels participated in study. In this study, it is thought that education levels of parents of students participating in study may affect students' perspectives on research subject. So, data on education levels of parents are also included. According to this, 6 (2.4\%) of mothers are illiterate, 7 (2.8\%) are literate, $65(25.6 \%)$ are primary school graduates, 60 (23.6\%) are secondary school graduates, $69(27.2 \%)$ high school graduates, 14 (5.5\%) associate degree graduates and 13 (13.0\%) Bachelor's degree. There is no mother with a master's or doctoral degree.
Considering education level of fathers of participants, 5 (2.0\%) are illiterate, $3(1.2 \%)$ are literate, $35(13.8 \%)$ are primary school, $54(21.3 \%)$ are secondary school graduates, 68 (26.8\%) high school graduates, 29 (11.4\%) associate degree and 60 (23.6\%) undergraduate degree graduates. There is no father with a master's or doctorate degree.

\section{Constructing Item Pool}

Steps followed in creating the items of scale is given below in paragraphs.

In process of developing scale items, first of all, literature that would prepare theoretical ground for study was scanned (Bilton, 2010; Donaldson \& Goering, 1970; McKenzie, 2000; Miller \& Kuhaneck, 2008; Rivkin, 2000; Gass \& Priest, 2005). Then, 11 open-ended questions were asked to reveal attitudes and views of secondary school students about outdoor games. Asking open-ended questions to a small heterogeneous group representing the group to which scale will be applied before writing items will positively affect consistency and content validity of items of tool (Tavşancıl, 2019; Tezbaşaran, 1997). These questions asked in this context are listed in Table 2:

Table 1. Demographic Information of Participants

\begin{tabular}{|c|c|c|c|}
\hline Variables & & $N$ & $\%$ \\
\hline Gender & $\begin{array}{l}\text { Female } \\
\text { Male }\end{array}$ & $\begin{array}{l}152 \\
102\end{array}$ & $\begin{array}{l}59.8 \\
40.2\end{array}$ \\
\hline \multirow[t]{4}{*}{ Grade } & 5th Grade & 54 & 21.3 \\
\hline & 6th Grade & 81 & 31.9 \\
\hline & 7th Grade & 64 & 25.2 \\
\hline & 8th Grade & 55 & 21.7 \\
\hline \multirow[t]{9}{*}{ Education Level of Mothers } & Illiterate & 6 & 2.4 \\
\hline & Literate & 7 & 2.8 \\
\hline & Primary school graduate & 65 & 25.6 \\
\hline & Secondary school graduate & 60 & 23.6 \\
\hline & High school graduate & 69 & 27.2 \\
\hline & Associate degree graduate & 14 & 5.5 \\
\hline & Bachelor's degree & 13 & 13.0 \\
\hline & Master's degree & - & - \\
\hline & PhD graduate & - & - \\
\hline \multirow[t]{9}{*}{ Education Level of Fathers } & Illiterate & 5 & 2.0 \\
\hline & Literate & 3 & 1.2 \\
\hline & Primary school graduate & 35 & 13.8 \\
\hline & Secondary school graduate & 54 & 21.3 \\
\hline & High school graduate & 68 & 26.8 \\
\hline & Associate degree graduate & 29 & 11.4 \\
\hline & Bachelor's degree & 60 & 23.6 \\
\hline & Master's degree & - & \\
\hline & $\mathrm{PhD}$ graduate & - & \\
\hline
\end{tabular}


Table 2: Interview Questions Used Before Item Pooling

\begin{tabular}{ll} 
Number & Questions \\
\hline 1 & Which games do you want to play outdoor? Why do you want to play those games? \\
2 & Which games do you play at school garden? Why are you playing those games? \\
3 & What kind of activities do you play outdoor at school? \\
4 & Can you observe the subjects you learned at school in outdoor (school garden, forest, amusement park, park, etc.)? \\
5 & Do your teachers give examples of outdoor elements at school? Can you explain examples? What are your feelings about these \\
6 & examples? Are you interested? \\
7 & With which lessons can you associate outdoor games with at school? How do you feel when you play these games? \\
8 & If you want to design a playground, how would you like the design of this garden, the features, colors, toys, plants, etc. to be? \\
9 & What do you pay attention to when playing outdoor? \\
10 & Which playgrounds do you use in outdoor? (School garden, neighborhood, street, park...) \\
11 & What do you think about outdoor lessons? How would you feel if your lessons took place especially outdoors or if you learned through \\
& various outdoor activities?
\end{tabular}

After feedback from secondary school students, many attitude statements were formed. It is recommended that while writing items with attitude expressions, the number of items planned to be used in scale should be three or four times (Tezbaşaran, 1997). For this reason, an item pool consisting of 75 items was created. Cognitive, affective and behavioral domains were taken into account in creation of attitude statements (Tavşancil, 2019). Literature was used to create item pool.

In order to ensure content validity, opinions of 2 lecturers working in the Department of Curriculum and Instruction and Science Department of Afyon Kocatepe University were consulted. In addition, the opinions of one literature teacher working in a high school affiliated to the Ministry of National Education were taken. A preliminary test was made in a group of 10 middle school students. In line with feedbacks from experts and students, items were re-examined, corrections were made in some items and draft was removed from scale due to similarity and repetition of some items. Thus, 64 items remained in candidate scale.

Prepared 64-item draft scale was applied to sample group in order to analyze its validity and reliability. Trend regarding attitude scales in recent years is to create response categories in five or seven dimensions (Finstad, 2010; Johns, 2010). In this scale, scoring requiring a 5-point Likert-type response was preferred. Items were graded as "strongly agree (5)", "agree (4)”, “a little agree (3)”, "disagree (2)”, "strongly disagree (1)”.

\section{Data Collection and Statistical Analysis}

Draft form of the Secondary School Students' Attitude Scale towards Outdoor Games was carried out in spring semester of 2020-2021 academic year. Ethics approval was obtained from Afyon Kocatepe University Social and Human Sciences Scientific Research and Publication Ethics Committee before scale was started to be implemented. Scale was applied to secondary school students on a voluntary basis. Data obtained were transferred to computer and positive items were graded starting from 5 and negative items starting from 1. Exploratory factor analysis and confirmatory factor analysis were used in analysis of data. Kaiser-Meyer-Olkin (KMO) analysis was used to determine suitability of scale for exploratory factor analysis, and Barlett's analysis test was used to determine sample test size. With exploratory factor analysis, subscales and their factor load values were determined (Büyüköztürk, 2012). Reliability of each subscale and the whole scale was determined by Cronbach's alpha coefficient. In test-retest analysis, Pearson Correlation Coefficient and independent groups t-test were applied.

\section{FINDINGS}

In this section, analyzes made to determine psychometric properties of attitude scale, which is being developed to determine the attitudes of secondary school students towards outdoor games, are included. The first analysis to be made during the development of a scale was exploratory factor analysis. In next step, confirmatory factor analysis results were included in order to determine to what extent items obtained as a result of exploratory factor analysis were sufficient for construct validity. Then, internal consistency reliability calculations were included.

One of the analyzes to be done to determine construct validity of a scale is factor analysis (Worthington \& Whittaker, 2006; Gürbüz \& Şahin, 2014). However, before applying exploratory factor analysis, sample size should be appropriate. It should be determined whether data show a normal distribution and correlation between items should be tested for factor analysis. For this, Kaiser Meyer Olkin (KMO) and Bartlett tests were applied. The KMO value was 
found to be 949 . This value shows that data are suitable for factor analysis. If $\mathrm{KMO}$ value is .60 or above, it is considered as sufficient (Tabachnick \& Fidell, 2001). As a result of Barlett test, chi-square value $=4218.69 ; \mathrm{df}=.406$ and $\mathrm{p}=.000$. These values also show that data have a normal distribution (Gorsush, 1997; Tabachnick \& Fidell, 2001). Data related to these are given in Table 3:

Table 3: KMO and Bartlett Test Results of Secondary School Students' Attitude Scale towards Outdoor Games

\begin{tabular}{lll}
\hline Kaiser-Meyer-Olkin & & .949 \\
Bartlet Test & Chi-kare & 4218.690 \\
& df & .406 \\
& $\mathrm{p}$ & .000 \\
\hline
\end{tabular}

\section{Findings Obtained from Exploratory Factor Analysis}

Factor analysis was conducted to determine factors of the Secondary School Students' Attitude Scale towards Outdoor Games and items to be included in these factors. Exploratory

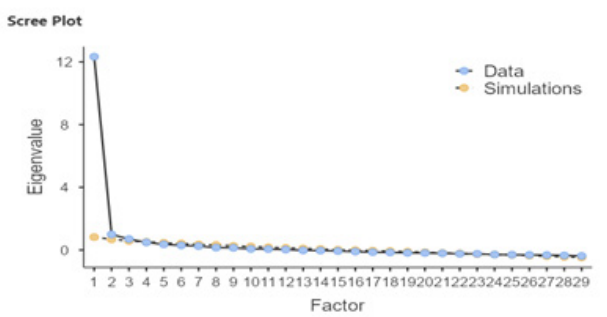

Fig. 1: Aggregation Graph of Factor Eigen Values

Table 4: Total Variance Table of Secondary School Students' Attitude Scale towards Outdoor Games

\begin{tabular}{|c|c|c|c|c|c|c|c|c|c|}
\hline \multirow[t]{2}{*}{ Items } & \multicolumn{3}{|c|}{ Initial Eigenvalues } & \multicolumn{3}{|c|}{ Total Factor Loads } & \multicolumn{3}{|c|}{ Factor Load Rotated Total } \\
\hline & Total & Variance\% & Cumulative\% & Total & Variance\% & Cumulative\% & Total & Variance\% & Cumulative\% \\
\hline 1 & 10.919 & 43.271 & 43.271 & 10.919 & 43.271 & 43.271 & 5.615 & 22.253 & 22.253 \\
\hline 2 & 1.469 & 5.821 & 49.091 & 1.469 & 5.821 & 49.091 & 5.010 & 19.855 & 42.108 \\
\hline 3 & 1.256 & 4.979 & 54.070 & 1.256 & 4.979 & 54.070 & 3.019 & 11.963 & 54.070 \\
\hline 4 & .989 & 3.920 & 57.991 & & & & & & \\
\hline 5 & .934 & 3.700 & 61.691 & & & & & & \\
\hline 6 & .899 & 3.561 & 65.251 & & & & & & \\
\hline 7 & .806 & 3.193 & 68.444 & & & & & & \\
\hline 8 & .700 & 2.773 & 71.217 & & & & & & \\
\hline 9 & .649 & 2.570 & 73.788 & & & & & & \\
\hline 10 & .599 & 2.375 & 76.162 & & & & & & \\
\hline 11 & .587 & 2.326 & 78.488 & & & & & & \\
\hline 12 & .531 & 2.102 & 80.590 & & & & & & \\
\hline 13 & .492 & 1.951 & 82.541 & & & & & & \\
\hline 14 & .434 & 1.720 & 84.261 & & & & & & \\
\hline 15 & .412 & 1.634 & 85.895 & & & & & & \\
\hline 16 & .394 & 1.563 & 87.458 & & & & & & \\
\hline 17 & .383 & 1.516 & 88.974 & & & & & & \\
\hline 18 & .343 & 1.359 & 90.333 & & & & & & \\
\hline 19 & .320 & 1.266 & 91.599 & & & & & & \\
\hline 20 & .294 & 1.165 & 92.764 & & & & & & \\
\hline 21 & .291 & 1.153 & 93.916 & & & & & & \\
\hline 22 & .276 & 1.095 & 95.012 & & & & & & \\
\hline 23 & .259 & 1.028 & 96.039 & & & & & & \\
\hline 24 & .214 & .848 & 96.887 & & & & & & \\
\hline 25 & .196 & .776 & 97.663 & & & & & & \\
\hline 26 & .172 & .681 & 98.344 & & & & & & \\
\hline 27 & .160 & .679 & 99.052 & & & & & & \\
\hline 28 & .153 & .636 & 99.400 & & & & & & \\
\hline 29 & .123 & .607 & 100.00 & & & & & & \\
\hline
\end{tabular}


factor analysis, which aims to explain scale with a small number of factors by gathering variables that measure same structure or quality, examines whether feature to be measured can be expressed with a few basic factors (Gürbüz \& Şahin, 2014). There are many methods for factoring items or obtaining factors, but the most common is principal component analysis. In this study, factors were determined by principal component analysis. In factor analysis, Varimax Rotation technique was used to gather items that have a high correlation with each other in a factor (Tavşancıl, 2019). As a result of exploratory factor analysis, the first factor number of scale was 14 and total variance value was $66.759 \%$. When items in these factors were examined, it was seen that some items had a high factor loading in more than one factor. While performing factor analysis, it is recommended that items' factor load values should be .30 or higher. The items should not be included in more than one factor and the difference between factor loads of items should be more than .10 (Büyüköztürk, 2011; Tavşancıl, 2019). Items with factor loadings less than .10 and items with factor loads less than .30 $(4,5,7,8,19,23,27,28,32,33,34,35,36,42,43,44,45,46,47,49,50,51$, $52,53,54,55,56,57,58,60,61,62,63,64)$ were excluded from scale. However, items 26, 54, and 62 were found as factors alone. Since single-item factors were extremely weak to represent a structure, these items were excluded from scale. Items were removed one by one from draft scale and necessary analyzes were made. After items were removed from scale, scree pilot based on eigenvalues was also used in order to determine the number of factors (Büyüköztürk, 2012). The graph is shown in Figure 1:

As it is seen in Figure 1, scale consists of 29 items and three factors, according to aggregation graph of factor eigenvalues. Total variance of these items and factors was calculated as $54.070 \%$. Eigenvalues, variance percentages and total variance percentages for these are shown in Table 4:

As seen in Table 4, three factors emerged as a result of exploratory factor analysis. Variance explanation percentages of these three factors were found to be $22.253 \%, 19.855 \%$ and $11.953 \%$, respectively. Three factors obtained explain $54.070 \%$ of total variance. In studies carried out in social sciences, it is considered sufficient to have a value between $40 \%$ and $60 \%$ of total variance (Tezci, 2016). Accordingly, it is seen that total variance value of the Secondary School Students' Attitude Scale towards Outdoor Games is sufficient. Factor loads of items in the Secondary School Students' Attitude Scale towards Outdoor Games, in other words, data on the rotated components matrix are given in Table 5:

Table 5 contains data on the rotated components matrix. While applying exploratory factor analysis, axis rotation is applied in order to ensure that factors obtained are independent and to make clear and meaningful comments. With this application, while the load of an item on one factor increases, the load on the other factor decreases. Thus, it is determined in which factors the items give a high correlation
Table 5. Rotated Components Matrix Table of Secondary School Students' Attitudes towards Outdoor Games Scale

\begin{tabular}{|c|c|c|c|}
\hline \multirow[t]{2}{*}{ Items } & \multicolumn{3}{|c|}{ Facyors } \\
\hline & 1 & 2 & 3 \\
\hline Item 16 & 0.819 & & \\
\hline Item 12 & 0.763 & & \\
\hline Item 22 & 0.809 & & \\
\hline Item 11 & 0.727 & & \\
\hline Item 24 & 0.695 & & \\
\hline Item3 & 0.703 & & \\
\hline Item 14 & 0.690 & & \\
\hline Item 25 & 0.697 & & \\
\hline Item 17 & 0.729 & & \\
\hline Item 10 & 0.591 & & \\
\hline Item 1 & 0.637 & & \\
\hline Item 13 & 0.642 & & \\
\hline Item39 & & 0.713 & \\
\hline Item41 & & 0.700 & \\
\hline Item 29 & & 0.745 & \\
\hline Item37 & & 0.725 & \\
\hline Item30 & & 0.674 & \\
\hline Item 48 & & 0.662 & \\
\hline Item 21 & & 0.748 & \\
\hline Item 40 & & 0.663 & \\
\hline Item 38 & & 0.700 & \\
\hline Item 18 & & 0.546 & \\
\hline Item 31 & & 0.563 & \\
\hline Item6 & & & 0.726 \\
\hline Item2 & & & 0.714 \\
\hline Item 20 & & & 0.556 \\
\hline Item 15 & & & 0.630 \\
\hline Item56 & & & 0.569 \\
\hline Item9 & & & 0.682 \\
\hline
\end{tabular}

(Büyüköztürk, 2012). For this purpose, rotation process was applied in order to gather items that are highly correlated with each other in a factor. Accordingly, as seen in Table 5, the factor loads of 29 items in scale ranged from .54 to .81 . Results obtained show that 29 items are also qualified to be included in scale

For quantitative studies, analysis procedure(s) and the statistical methods used and their justification for appropriateness for each research question or hypothesis should be explained in detail in this section. Data analysis procedures in qualitative studies should also be discussed comprehensively. 


\section{Findings Related to Reliability Analysis}

In order to determine reliability of the Secondary School Students' Attitudes towards Outdoor Games Scale, item-total correlation analysis was applied to determine relationship between scores obtained from items belonging to scale and total score obtained from test. In addition, in order to determine the power of discrimination regarding reliability of scale, t-test based on difference between lower and upper group averages (based on the internal consistency criterion) was applied to 29 items in scale. Difference between t-test and mean of independent groups for each scale item of $27 \%$ lower and upper groups at two ends of scale scores was examined. Findings from these analyzes are presented in Table 6:

As seen in Table 6, item-total correlation coefficients of the Secondary School Students' Attitude Scale towards Outdoor Games range from 0.48 to 0.73 , and it is seen that correlation coefficients of all items are significant. The fact that these correlation coefficients are positive and high indicates that items exemplify similar behaviors and internal consistency of test is high. It is stated that items with an item-total score correlation of 0.30 and higher are highly discriminatory, items between 0.20 and 0.30 can be included in test or should be corrected in mandatory situations, and items lower than 0.20 should be removed from test (Büyüköztürk, 2012). Accordingly, it is seen that all items in the Secondary School Students' Attitude Scale towards Outdoor Games have a good distinguishing feature. As a result of t-test for $27 \%$ lower and upper groups given in Table 6, it was determined that mean score difference of all items was significant.

Cronbach alpha reliability coefficient was also calculated to determine reliability of the Secondary School Students' Attitudes Scale towards Outdoor Games. Findings obtained here are given in Table 7:

Table 6: Findings Related to Item-Total Correlation and t-Test for 27\% Lower and Upper Groups

\begin{tabular}{|c|c|c|c|c|c|}
\hline \multirow[b]{2}{*}{ Factors } & \multirow[b]{2}{*}{ Item Number } & \multicolumn{2}{|c|}{ Item-Total Correlation Values } & \multicolumn{2}{|c|}{$t$-Test Values for 27\% Lower and Upper Groups } \\
\hline & & rvalue & $p$ value & tvalue & $p$ value \\
\hline \multirow{12}{*}{ Factor 1} & Item 16 & .721 & .000 & 8.961 & .000 \\
\hline & Item 12 & .672 & .000 & 9.025 & .000 \\
\hline & Item 22 & .732 & .000 & 8.388 & .000 \\
\hline & Item 11 & .656 & .000 & 8.607 & .000 \\
\hline & Item 24 & .647 & .000 & 10.096 & .000 \\
\hline & Item3 & .658 & .000 & 8.308 & .000 \\
\hline & Item14 & .648 & .000 & 10.465 & .000 \\
\hline & Item 25 & .672 & .000 & 10.299 & .000 \\
\hline & Item 17 & .718 & .000 & 13.167 & .000 \\
\hline & Item 10 & .556 & .000 & 9.493 & .000 \\
\hline & Item 1 & .606 & .000 & 9.049 & .000 \\
\hline & Item 13 & .613 & .000 & 12.598 & .000 \\
\hline \multirow{11}{*}{ Factor 2} & Item39 & .644 & .000 & 12.381 & .000 \\
\hline & Item 41 & .631 & .000 & 9.625 & .000 \\
\hline & Item 29 & .697 & .000 & 12.798 & .000 \\
\hline & Item37 & .664 & .000 & 13.729 & .000 \\
\hline & Item30 & .638 & .000 & 10.669 & .000 \\
\hline & Item 48 & .613 & .000 & 10.042 & .000 \\
\hline & Item 21 & .727 & .000 & 12.815 & .000 \\
\hline & Item 40 & .635 & .000 & 8.880 & .000 \\
\hline & Item38 & .659 & .000 & 12.165 & .000 \\
\hline & Item 18 & .521 & .000 & 8.657 & .000 \\
\hline & Item31 & .534 & .000 & 7.656 & .000 \\
\hline \multirow{6}{*}{ Factor 3} & Item6 & .648 & .000 & 10.630 & .000 \\
\hline & Item 2 & .641 & .000 & 11.789 & .000 \\
\hline & Item 20 & .488 & .000 & 8.433 & .000 \\
\hline & Item 15 & .559 & .000 & 10.105 & .000 \\
\hline & Item56 & .506 & .000 & 9.272 & .000 \\
\hline & Item 9 & .633 & .000 & 12.236 & .000 \\
\hline
\end{tabular}


Table 7: Cronbach Alpha Values

\begin{tabular}{ll}
\hline & Cronbach alpha $(\alpha)$ \\
\hline Factor 1 & 0.91 \\
Factor 2 & 0.90 \\
Factor 3 & 0.80 \\
Total & 0.95 \\
\hline
\end{tabular}

As seen in Table 7, a value for total score obtained from the Secondary School Students' Attitude Scale towards Outdoor Games was 0.95 and $\alpha$ values for sub-dimensions were 0.91 , 0.90 and 0.80 . Reliability coefficient of $\alpha$, which is a measure of consistency of scores of items with total test scores, is "not reliable" if it is between $0.00-0.40$, "low reliability" is between $0.40-0.60,0.60-0.80$ between $0.80-1.00$, it is stated as "highly reliable" (Akgül \& Çevik, 2003; Kalayc1, 2008). This shows that the Secondary School Students' Attitude Scale towards Outdoor Games is highly reliable. Finally, Pearson correlation analysis was applied to determine relationships between factors within scope of reliability analysis. Findings are given in Table 8:

According to Table 8, there is a positive and significant relationship between factors. It is stated that correlation coefficient is "weak" if it is less than 0.30, "moderate" if it is between 0.30-0.70, and "high" if it is greater than 0.70 (Büyüköztürk, Çokluk-Bökeoğlu \& Köklü, 2011). Accordingly, it can be said that relationship between all factors is at a high level. These results show that all three factors in the Secondary School Students' Attitude Scale towards Outdoor Games are in same stucture.

\section{Findings Related to Test-Retest Analysis}

Calculation of correlation coefficient between two measurement values by applying a developed measurement tool to same sample group, under the same conditions, continuously or at a certain time interval, is an analysis of reliability of scale. Recommended timeframe ranges from 15 to 30 days. Thus, test-retest reliability value of scale is calculated by looking at correlation between two applications (Seçer, 2015; Tavşancıl, 2019). The most important point is that interval does not adversely affect reliability of scale. While interval is very short, it makes it easier for participants to remember again, while length of interval may cause some changes in measured properties, thus not providing same conditions for two measurements (Tavşancıl, 2019). Data on test-retest findings are given in Table 9:

Table 9 contains test-retest analyzes with 30 participants to examine whether “The Secondary School Students' Attitude Scale towards Outdoor Games", which consists of three factors, changes over time. Findings show that there is a strong positive relationship between two applications $(r=0.973)$. For invariance, mean scores obtained from the first and second applications, which were applied with a 4-week interval, were
Table 8: Results of Pearson Correlation Analysis Between Factors

\begin{tabular}{lllll}
\hline & Factor 1 & Factor 2 & Factor 3 & Total \\
\hline Factor 1 & 1 & & & \\
Factor 2 & ${ }^{*} 791$ & 1 & & \\
Factor 3 & ${ }^{*} .715$ & $* .710$ & 1 & \\
Total & $* .934$ & ${ }^{*} .934$ & ${ }^{*} .849$ & 1 \\
\hline
\end{tabular}

Table 9: Test-Retest Analysis Values of Secondary School Students' Attitude Scale towards Outdoor Games

\begin{tabular}{lll}
\hline$N=30$ & Application I & Application II \\
\hline Mean & 95.78 & 98.69 \\
Standard deviation & 18.63 & 17.22 \\
Median & 129.3 & 131.2 \\
Minimum Score & 87 & 100 \\
Maximum Score & 143 & 145 \\
Correlation & 0.973 & \\
t value & 1.036 & \\
p value & $0.08>0.05$ & \\
Cronbach Alpha & 0.89 & \\
\hline
\end{tabular}

compared with dependent groups t-test and no statistically significant difference was found between two mean scores $(\mathrm{t}=1.036 ; \mathrm{p}>0.00)$. In addition, Cronbach alpha coefficient was found to be .89 in test-retest group. In each test-retest analysis, a person's first and second application scores were compared.

\section{Findings on Confirmatory Factor Analysis}

Confirmatory factor analysis is used to test whether there is a sufficient relationship between determined factors, which variables are related to which factors, whether the factors are independent from each other and whether factors are sufficient to explain model (Özdamar, 2004). In this framework, a model was created according to three dimensions reached at the end of exploratory factor analysis of the Secondary School Students' Attitude Scale towards Outdoor Games and this model was tested with confirmatory factor analysis. Descriptive statistics for confirmatory factor analysis are given in Table 10 below:

According to Table 10, as a result of the first level confirmatory factor analysis of the Secondary School Students' Attitudes Scale towards Outdoor Games, it was found that factor loads varied between .477 and .739 and all items were significant. In addition, covariances among the factors of the Secondary School Students' Attitude Scale towards Outdoor Games were examined and findings are given in Table 11:

According to Table 11, covariance values among factors of the Secondary School Students' Attitudes towards Outdoor Games were significant $(\mathrm{p}<.05)$ and there was a positive correlation between factors. The covariance between Factor 1 and Factor 2 was found to be .854 , the covariance between Factor 1 and Factor 3 was .829, and the covariance between 
Table 10: Confirmatory Factor Analysis Values of Secondary School Students' Attitude Scale towards Outdoor Games

\begin{tabular}{|c|c|c|c|c|c|c|c|c|}
\hline \multirow[b]{2}{*}{ Factors } & \multirow[b]{2}{*}{ Items } & \multirow[b]{2}{*}{ Value } & \multicolumn{5}{|c|}{ 95\% Confidence Interval } & \multirow[b]{2}{*}{$\begin{array}{l}\text { Standard } \\
\text { Value }\end{array}$} \\
\hline & & & $\begin{array}{l}\text { Standard } \\
\text { error }\end{array}$ & Lower & Upper & $Z$ & $p$ & \\
\hline \multirow{12}{*}{ 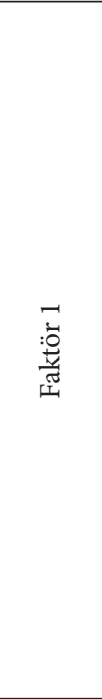 } & 16) I use my energy better in outdoor games. & 0.628 & 0.0400 & 0.550 & 0.707 & 15.70 & .001 & 0.819 \\
\hline & 12) I feel free in outdoor games. & 0.573 & 0.0405 & 0.494 & 0.653 & 14.14 & .001 & 0.763 \\
\hline & 22) I have a lot of fun in outdoor games. & 0.614 & 0.0398 & 0.536 & 0.692 & 15.41 & .001 & 0.809 \\
\hline & 11) I feel happy in outdoor games. & 0.499 & 0.0378 & 0.425 & 0.573 & 13.20 & .001 & 0.727 \\
\hline & 24) I use many of my skills in outdoor games. & 0.566 & 0.0455 & 0.477 & 0.655 & 12.42 & .001 & 0.695 \\
\hline & $\begin{array}{l}\text { 3) Contacting natural environment in outdoor } \\
\text { games makes me happy. }\end{array}$ & 0.603 & 0.0478 & 0.510 & 0.697 & 12.63 & .001 & 0.703 \\
\hline & $\begin{array}{l}\text { 14) Since I think that I am not restricted in } \\
\text { outdoor games. I can learn more easily. }\end{array}$ & 0.628 & 0.0510 & 0.528 & 0.728 & 12.31 & .001 & 0.690 \\
\hline & $\begin{array}{l}\text { 25) I can express myself better in outdoor } \\
\text { games. }\end{array}$ & 0.638 & 0.0511 & 0.538 & 0.738 & 12.48 & .001 & 0.697 \\
\hline & $\begin{array}{l}\text { 17) I think I will learn subjects better in } \\
\text { outdoor games. }\end{array}$ & 0.688 & 0.0519 & 0.586 & 0.790 & 13.25 & .001 & 0.729 \\
\hline & 10) I have positive emotions in outdoor games. & 0.477 & 0.0471 & 0.384 & 0.569 & 10.11 & .001 & 0.591 \\
\hline & 1) I feel comfortable in outdoor games. & 0.546 & 0.0493 & 0.450 & 0.643 & 11.09 & .001 & 0.637 \\
\hline & $\begin{array}{l}\text { 13) I do not have difficulty when I am in a } \\
\text { decision-making situation in outdoor games. }\end{array}$ & 0.681 & 0.0608 & 0.562 & 0.800 & 11.20 & .001 & 0.642 \\
\hline \multirow{11}{*}{ 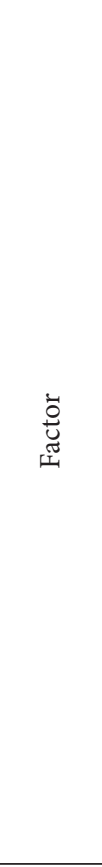 } & $\begin{array}{l}\text { 39) Outdoor games help me focus more on } \\
\text { my studies. }\end{array}$ & 0.739 & 0.0578 & 0.626 & 0.852 & 12.78 & .001 & 0.713 \\
\hline & $\begin{array}{l}\text { 41) I think I will learn more easily with nature } \\
\text { sports. }\end{array}$ & 0.700 & 0.0561 & 0.590 & 0.810 & 12.47 & .001 & 0.700 \\
\hline & $\begin{array}{l}\text { 29) Outdoor games help me cope with } \\
\text { challenges I face. }\end{array}$ & 0.725 & 0.0534 & 0.620 & 0.830 & 13.58 & .001 & 0.745 \\
\hline & $\begin{array}{l}\text { 37) No matter which lesson is used. outdoor } \\
\text { games ensure that what I learn is permanent. }\end{array}$ & 0.698 & 0.0534 & 0.594 & 0.803 & 13.09 & .001 & 0.725 \\
\hline & $\begin{array}{l}\text { 30) Lessons become more fun with outdoor } \\
\text { games. }\end{array}$ & 0.590 & 0.0498 & 0.493 & 0.688 & 11.86 & .001 & 0.674 \\
\hline & $\begin{array}{l}\text { 48) School gardens are important in explaining } \\
\text { lessons through outdoor play. }\end{array}$ & 0.624 & 0.0539 & 0.519 & 0.730 & 11.59 & .001 & 0.662 \\
\hline & $\begin{array}{l}\text { 21) I think my mind gets stronger in outdoor } \\
\text { games. }\end{array}$ & 0.714 & 0.0523 & 0.612 & 0.817 & 13.66 & .001 & 0.748 \\
\hline & $\begin{array}{l}\text { 40) Nature walks are important in } \\
\text { understanding the importance of environment. }\end{array}$ & 0.572 & 0.0493 & 0.475 & 0.669 & 11.61 & .001 & 0.663 \\
\hline & $\begin{array}{l}\text { 38) I learn a lot in free games that I play } \\
\text { outdoors with my friends. }\end{array}$ & 0.650 & 0.0521 & 0.548 & 0.752 & 12.47 & .001 & 0.700 \\
\hline & $\begin{array}{l}\text { 18) I think I can learn more in outdoor games } \\
\text { than in classroom. }\end{array}$ & 0.599 & 0.0656 & 0.471 & 0.728 & 9.13 & .001 & 0.546 \\
\hline & $\begin{array}{l}\text { 31) If I want to play outdoors. I prefer green } \\
\text { areas first. }\end{array}$ & 0.576 & 0.0608 & 0.457 & 0.695 & 9.47 & .001 & 0.563 \\
\hline \multirow{6}{*}{ 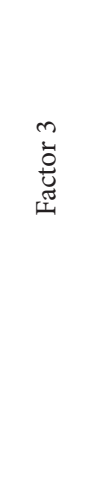 } & $\begin{array}{l}\text { 6) I use my guessing skills more comfortably } \\
\text { in outdoor games. }\end{array}$ & 0.639 & 0.0502 & 0.541 & 0.738 & 12.72 & .001 & 0.726 \\
\hline & 2) I observe nature better in outdoor games. & 0.605 & 0.0486 & 0.510 & 0.700 & 12.46 & .001 & 0.714 \\
\hline & $\begin{array}{l}\text { 20) When I run in outdoor games. I wonder } \\
\text { why our heart rate changes. }\end{array}$ & 0.668 & 0.0737 & 0.524 & 0.813 & 9.07 & .001 & 0.556 \\
\hline & $\begin{array}{l}\text { 15) I wonder why some situations I encounter } \\
\text { in outdoor games (like why I accelerate while } \\
\text { sliding down the slide.....). }\end{array}$ & 0.707 & 0.0668 & 0.576 & 0.838 & 10.58 & .001 & 0.630 \\
\hline & $\begin{array}{l}\text { 56) Green areas in playgrounds help me to } \\
\text { observe many living things. }\end{array}$ & 0.610 & 0.0654 & 0.482 & 0.738 & 9.33 & .001 & 0.569 \\
\hline & $\begin{array}{l}\text { 9) I can make better inferences in outdoor } \\
\text { games. }\end{array}$ & 0.593 & 0.0507 & 0.494 & 0.693 & 11.71 & .001 & 0.682 \\
\hline
\end{tabular}


Attitudes of Secondary School Students towards Outdoor Games: A Scale Development Study

Table 11: Factor Covariances of Secondary School Students' Attitude Scale towards Outdoor Games

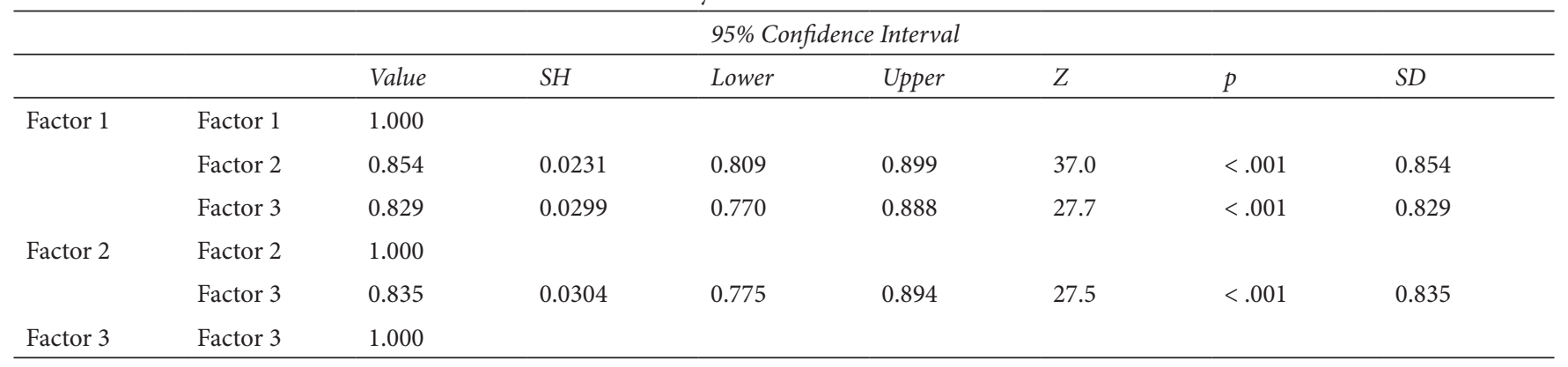

Factor 2 and Factor 3 was .835. This shows that three-factor structure of the Secondary School Students' Attitude Scale towards Outdoor Games was confirmed.

In next step of the confirmatory factor analysis, the fit indexes of the Secondary School Students' Attitude Scale towards Outdoor Games were examined. While there is no consensus on which index will be accepted as a standard when deciding whether model created by confirmatory factor analysis is compatible with theory, various fit indices such as $\chi 2$, $\chi 2 / s d$, GFI, CFI, TLI, GFI, RMSEA, RMR and SRMR are used (Munro, 2005; cited in Çapık, 2014). In this context, fit indexes of the Secondary School Students' Attitude Scale towards Outdoor Games, $\chi 2=.851, \mathrm{df}=.374, \chi 2 / \mathrm{df}=2.275$, RMSEA $=0.0709$, SRMR $=0.0509, \mathrm{CFI}=0.881$, TLI $=0.871$. If chi-square/degree of freedom $\left(\chi^{2} / \mathrm{sd}\right)$ value is less than 5 , model is considered to have good fit, and if it is less than 3, model is considered to have a very good fit. For RMSEA, which is error (mismatch) index of model, 0.08 is accepted as acceptable fit, and less than 0.05 is considered perfect fit. In addition, SRMR values lower than 0.08 are accepted as acceptable fit. CFI and TLI values between .95 and 1.00 are indicated as perfect fit, and between .90 and .95 an acceptable fit value. It is also stated that TLI value is accepted as a threshold value up to .80 (Byrne, 1998; Hu \& Bentler, 1999; Marsh, Hau, Artelt, Baumert, \& Peschar, 2006; Kline, 2011; Çokluk, Şekercioğlu, \& Büyüköztürk, 2012; Elderyoğlu , 2017). Accordingly, Chisquare/degree of freedom ( $\left.\chi^{2} / \mathrm{sd}\right)$ value of the Secondary School Students' Attitudes towards Outdoor Games Scale has a good fit, RMSEA and SRMR values have an acceptable fit, and CFI and TLI values are very close to acceptable fit. Path Diagram of model created for the Secondary School Students' Attitude Scale towards Outdoor Games is given in Figure 2 below:

According to model given in Figure 2, the Secondary School Students' Attitude Scale towards Outdoor Games consists of 3 factors and 29 items. As a result, confirmatory factor analysis findings confirmed that model created was at an acceptable level.

\section{Discussion and Conclusion}

In this study, it was aimed to develop a scale to determine the attitudes of secondary school students towards outdoor games.

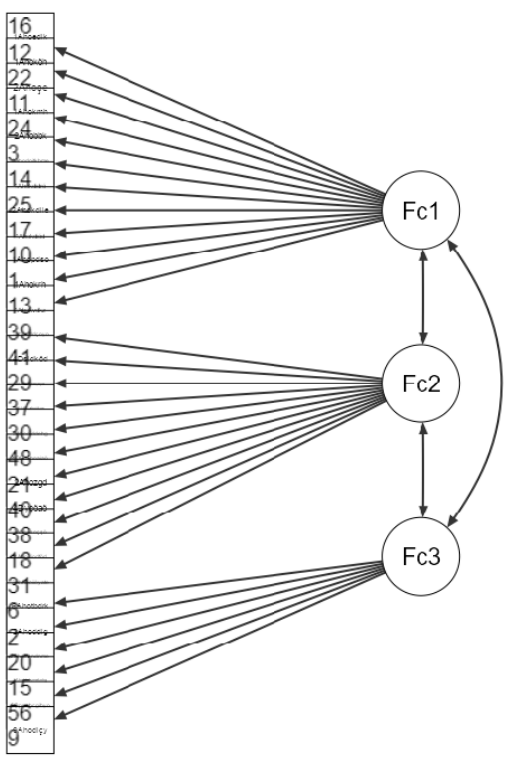

Fig: 2: Path Diagram

For this purpose, a 64-item 5-point Likert-type pre-trial form was created, aiming to measure students' attitudes towards outdoor games. Exploratory factor analysis was performed to ensure construct validity of scale. As a result of exploratory factor analysis, 29 items remained in trial form. KaiserMeyer-Olkin value obtained to control suitability of available data for factor analysis was calculated as .949 and Bartlett test was statistically significant. According to exploratory factor analysis, total variance was calculated as $54.070 \%$. As a result, a 3-dimensional scale consisting of 29 items was obtained. 12 of items in final version of scale were collected in first factor, 11 ones were in second factor and 6 ones were in third factor. Regarding reliability of scale, Cronbach Alpha reliability coefficient was found to be $\alpha=.95$. These values show that the measurement tool is valid and reliable. As a result of confirmatory factor analysis, acceptable fit values were reached with $\chi^{2}=851$, RMSEA $=0.0709$, SRMR $=0.0509, \mathrm{CFI}=0.881$ and $\mathrm{TLI}=0.871$. This shows that developed scale is a valid and reliable scale.

In a study conducted by Alat, Akgümüş and Cavali (2012), it was aimed to reveal thoughts, attitudes and practices of 
preschool teachers about outdoor activities. Within the scope of study, data were collected from teachers working in programs affiliated to Ministry of National Education, with different degrees of education and experience in different periods, using interview technique. It is seen that teachers mostly support outdoor activities and express their opinion that they contribute to development areas of students. In another study conducted by Aşkar (2021), activity type of outdoor activities in Integrated Family Support Education Guide (OBADER), Activity Book (2013) and Activity Book for Teachers (2018), which constitute materials of Preschool Education Program, were determined. It has been systematically examined in terms of variables such as field, subject, concepts it deals with and positioning of open air in event. Research data were carried out in line with qualitative research data collection techniques. As a result of research, it is stated that outdoor activities are included in relevant sources, but they are not enough. The results of these studies show that questions such as how outdoor games in learning environments should be planned and what is the need for this issue have not yet been fully answered. This developed scale can also be used as a need assessment tool on this subject.

In PISA (2006), students were asked how much time they spent learning different subjects in different environments in and outside of school, and their answers were "never", "less than 2 hours in a week", "less than 4 hours but more than 2 hours in a week", "one less than 6 hours a week but more than 4 hours", "more than 6 hours a week" were asked to classify them. Most of participants answered "less than 2 hours in a week". However, again in PISA 2006, participants stated not only time they spent in out-of-school environments, but also what kind of activities they participated in. These often include classes on school-related subjects held outside of normal school hours. In other words, they are activities outside school and home, which are held outdoors and are guided by non-school teachers or staff. This is an indication of how little time is spent on outdoor learning activities. Children who are physically active are more likely to become healthy adults (National Center for Health Statistics, 2004). Increase in time children spend in front of screen, physical inactivity and advertisement of unhealthy foods trigger obesity. Although American Academy of Pediatrics Committee (AAP) (2001) recommended that children younger than two should not watch television and that children older than two should watch no more than 1-2 hours a day, research suggested that $90 \%$ of children aged 4 to 6 years average 3 hours a day. It shows that they are connected to the screen for more than an hour. Guidelines published by National Sports and Physical Education Association (NASPE, 2010) recommended that preschoolers get at least one hour of intense physical activity a day, but research shows kids fall far behind this goal. This situation reveals necessity of outdoor games especially for young children. In this context, scale developed in this study can be used to determine the attitudes of secondary school students towards outdoor games. In this way, learning environments are shaped by determining needs of students mentioned above.

In study conducted by Mittelstaedt and Jones (2009), it was aimed to develop "Outdoor Recreation Self-Efficacy Scale". Bandura's self-efficacy theory has been tried to be discussed in context of outdoor activities. After factor analysis, two subscales emerged, Pleasure/Success (61.84\%) and Skills/ Competence (12.71\%). Scale constitutes $74.54 \%$ of total variance. While reliability value was calculated as $\alpha=.95$ in the first sub-dimension, Pleasure/Success sub-dimension, it was calculated as $\alpha=.94$ in Skills/Competence sub-dimension. For entire 17-item measurement tool, reliability coefficient value is $\alpha=.96$. There is a significant relationship between outdoor recreation self-efficacy scores of participants and their participation in outdoor recreation $(\mathrm{r}=.52 ; \mathrm{p}<.001)$. Results showed that having fun and enjoyment during outdoor recreational activities contributes more to a woman's self-efficacy than feeling capable or competent. Resulting measurement tool confirmed Bandura's thoughts on nature of self-efficacy. Researchers can use this tool with confidence, it provides a reliable and valid measure to assess self-efficacy of women participating in outdoor recreational activities. In this study, which deals with the attitudes of secondary school students towards outdoor games, there are 3 sub-dimensions and a total of 25 items. Ratio of explaining total variance of items in scale was determined as $54 \%$. Reliability value of measurement tool was calculated as .95. This value is accepted as one of important criteria of a reliable scale.

A study by Ouvry (2003) found that $93 \%$ of male participants believed that outdoor games helped their learning, and only 1 male participant ticked the 'undecided' box. On the other hand, $77 \%$ of female participants stated that they thought outdoor games helped them learn, while only $15 \%$ were undecided and 1 participant expressed a negative opinion. The view of Adams and Branco (2017) that outdoor learning activities offer authentic learning activities and combine them with the pleasure of exploring one's immediate environment supports Ouvry's (2003) study. Louv (2008) expressed their views on this issue from a much broader perspective. Louv emphasizes that almost all world societies avoid learning experience in nature and boundaries of learning environments are drawn very clearly. She stated that these boundaries become much thicker with inclusion of schools, families and teachers in these learning environments, and individuals have difficulty in reaching learning experience.

Bailey (1904) stated that teachers should avoid giving definitions and explanations to students, instead they should reach their own definitions by examining flower or leaf models. Students need to interact with real objects or phenomena and experience learning. While doing this, learning environments 
should not be made boring. Otherwise, ordinary classroom environments would only be physically modified. Bailey asked a group of students to go to nature and find a flower and show each other flower they found. Students stated that they should observe right thing before they go to nature and start searching. Secondly, it enabled students to understand what thing they were looking for meant and what kind of features it had. Third key step is to make sure students understand what they want to know. According to this theory of Bailey, results of these steps provide development of students' personal interest in the world of nature. However, it is stated that teaching that includes fun in nature is mostly exotic to children, and when children are removed from their natural environment, they are mostly not interested in learning. In this study, it was observed that students mostly stated that they learned better in outdoor games while asking open-ended questions to students during creation of item pool and collecting data about draft scale.

In study conducted by Schumann and Sibthorp (2014), a measurement tool was developed that aims to reveal selfefficacy beliefs of educators who teach outdoors. Errors in these self-beliefs, which are judgments about one's ability to successfully perform required teaching tasks, can have negative consequences for students' learning and safety in outdoor environments. In this study, two studies conducted to develop a self-efficacy scale were presented. In Study 1, data were collected from 303 participants in university outdoor programs. As a result of exploratory factor analysis, a 23-item measurement tool consisting of a 49 -item pool and 5 sub-scales emerged. In Study 2, data were collected from 200 National Outdoor Leadership School (NOLS) instructors and participants. Confirmatory Factor Analysis results showed an acceptable fit for a 22-item and 5-factor scale. In this study, acceptability of measurement tool developed by using both exploratory and confirmatory factor analysis was revealed.

A study by Outdoor Training (no date) organized "Girl Scout" programs and emphasized importance of experiential learning in training leaders to facilitate outdoor programs. This training has been recognized as a practical way of accustoming female students, in particular, to living in open environments. They also learned to play and teach outdoor games to students, to lead nature activities, and to live and work cooperatively in outdoor. Waite (2005) conducted a study with 334 participants in a town in the Southwest of England. The ages of participants ranged from 2 to 11 . The study includes five case studies that explore children's outdoor learning practices and their aspirations. The purpose of case studies is to critically evaluate implications of personal values associated with outdoors, including freedom and enjoyment and autonomy, a love of rich sensory environment, and physicality for pedagogical practice. As a result of case studies, it has been observed that barriers to the full use of outdoor learning potential continue. It has been stated that there are some reported problems between personal values of individuals and ongoing drive to improve standards in the UK, particularly that outdoor learning activities should be included in curriculum.

Whether learning environments are outdoors, parks, playgrounds, countryside, or any other open environment, they offer unlimited opportunities for learning. Children can turn a rock or a piece of wood upside down and find insects, worms, roots and fungi. They can look at clouds or collect leaves and observe various forms and textures in nature. They can hear birds or feel wind and become aware of entire sensory world beyond classroom door (Handler \& Epstein, 2010). Wells (2000) stated that children who see nature and have contact with nature get higher scores in concentration and self-discipline tests. Fjortoft (2001) stated that children who regularly play in natural environments have more advanced motor skills, including coordination, balance and agility. Exposure to natural environments supports children's cognitive development by improving their awareness, reasoning and observation skills (Pyle, 2002). Nature buffers impact of life stress on children and helps them cope with difficulties. The greater amount of exposure to nature, the greater benefits. Nature helps children develop their powers of observation and creativity and instills a sense of peace and oneness with the world (Crain, 2001). Children playing in nature have more positive feelings towards each other (Moore, 1996).

As seen in studies mentioned above, outdoor games support development areas of individuals in many ways. In this sense, it is extremely important to include such games in learning environments. Before determining qualities of games, determining the attitudes of students towards outdoor games can be seen as the first step in determining need at this point. In this study, validity and reliability studies of the "the Secondary School Students' Attitude Scale towards Outdoor Games" were carried out to fill this gap in the field.

\section{Limitation}

This study is limited to the opinions of secondary school students who participated in the research. The research was limited to the quantitative and qualitative research methods used. The study was carried out in the 2020-2021 academic year. Most of the data was collected online.

\section{References}

Adams, J. D. \& Branco, B. (2017). Extending parks into the classroom through Informal Learning and Place-based education. In P. Patrick (Ed.), Preparing informal science educators. Springer: The Netherlands, Finland.

Akgül, A. \& Çevik, O. (2003). İstatistiksel analiz teknikleri. Emek Ofset, Ankara.

Alat, Z., Akgümüş, Ö. \& Cavalı, D. (2012). Okul öncesi eğitimde açık hava etkinliklerine yönelik öğretmen görüş ve uygulamaları. Mersin Üniversitesi Eğitim Fakültesi Dergisi, 8(3), 47-62. 
Arnas, Y. A. (2007). Okul öncesi döneminde fen eğitimi. Ankara: Kök Yayıncılık.

American Academy of Pediatrics Committee (2001). Care of children in the emergency department: guidelines for preparedness. Pediatrics, 107(4), 777-781.

Andre, E. K. (2019). Outdoor fundamentals everything you need to know to stay safe. The Great Courses: The United States of America.

Aşkar, N. (2021). Açık havada eğitim: okul öncesi eğitim programı materyalleri bağlamında bir değerlendirme. Yaşadıkça Ĕ̆itim, 35(1), 132-153. https://doi.org/10.33308/26674874.20 $\underline{21351236}$

Athey, C. (1990). Extending thought in young children: a parent teacher partnership. London: Paul Chapman.

Bacon, F. (1987). Recusation des doctrines philosophiques et autres opuscules. Translated by Didier Deleule. Paris: Presses Universitaires de France

Bailey, L. H. (1904). The nature-study movement. In State of New York - Department of Agriculture

(Ed.), Cornell nature-study leafl ets: Being a selection, with revision, from the teachers' leafl ets, home nature-study lessons, junior naturalist monthlies and other publications from the College of Agriculture, Cornell University, Ithaca, N. Y., 1896-1904 (pp. 21-29). Albany, NY: J. B. Lyon.

Baldock, J. (2011). Composition and cycling of organic C in soil. In: Nutrient Cycling in Terrestrial Ecosystems (eds Marschner P, Rengel Z), pp. 1-35. Springer, Berlin, Heidelberg.

Beyaz Saray Çocukluk Çağı Obezitesi ile Mücade Topluluğu (The White House, "Presidential Memorandum: Establishing a Task Force on Childhood Obesity). (2010). Retrived on March 11, 2021 from http://www. whitehouse.gov/the-pressoffice/presidential-memorandum-establishing-atask-forcechildhood-obesity.

Bilton, H. (2010). Outdoor learning in the early years: management and innovation (3. Bask1). NY: Routledge.

Broström, S. (1997) Children's play: tools and symbols in frame play. Early Years.

Büyüköztürk, Ş. (2012). Sosyal bilimler için veri analizi el kitabı. Ankara: Pegem Yayınları.

Büyüköztürk, Ş., Çokluk-Bökeoğlu, Ö. \& Köklü, N. (2011). Sosyal bilimler için istatistik (7.bask1). Ankara: Pegem Akademi Yayıncilık.

Byrne, B. M. (1998). Structural equation modeling with LISREL, PRELIS and SIMPLIS: basic concepts, applications and programming. Mahwah, New Jersey: Lawrence Erlbaum Associates.

Child, D. (2006). The essentials of factor analysis. Continuum, London.

Comrey, A. L. \& Lee, H. B. (1992). A first course in factor analysis (2nd ed.). Hillsdale, NJ: Lawrence Erlbaum.

Cooper, A. (2015). Nature and the outdoor learning environment: The forgotten resource in early childhoodeducation. International Journal of Early Childhood Environmental Education, 3(1), 85 $-97$.

Cornish, A. (2006). Reaching EFA through multi-grade teaching. Armidale, Kardoorair Press, Armidale, Australia.

Crain, W. (2001). Now nature helps children develop. Montessori Life, Summer 2001.
Creswell, J. W. (2005). Educational research: Planning, conducting, and evaluating quantitative and qualitative research. Upper Saddle River, New Jersey: Pearson Education, Inc.

Çapık, C. (2014). Geçerlik ve güvenirlik çalışmalarında doğrulayıcı faktör analizinin kullanımı. Anadolu Hemşirelik ve Sağlık Bilimleri Dergisi, 17(3), 196-205.

Çavuşoğlu, H. (2013). Çocuk sağlı̆̆ı hemşireliği. Ankara: Sistem Ofset Basım Evi.

Çokluk, Ö. S., Şekercioğlu, G. \& Büyüköztürk, S. (2012). Sosyal bilimler için çok değişkenli istatistik: spss ve lisrel uygulamaları. Ankara: Pegem Akademi Yayıncilık.

DeLay, R. B. (1996). Constructing the uninhabited home: Participants' experience of nature during and following a wilderness trip. Unpublished Master's thesis. University of Alberta, Edmonton, Alberta.

Demiriz, S., Karadağ, A. \& Ulutaş, İ. (2003). Okulöncesi eğitim kurumlarında eğitim ortamı ve donanımı. Anı Yayıncılık, Ankara.

Dewey, J. (1938). Experience and education. New York, NY: Kappa Delta Pi.

Donaldson, G. W. \& Goering, O. H. (1970). Outdoor education: A synthesis. Clearinghouse on Rural Education and Small Schools. Retrived on March 12, 2021 from https://files.eric. ed.gov/fulltext/ED037286.pdf.

Dönmez Baykoç, N. (1992). Oyun kitabı. Esin Yayınevi: İstanbul.

Early Childhood Education Forum. (1998). Quality in Diversity. London: National Children's Bureau.

Finstad, K. (2010). The usability metric for user experience. Interacting with Computers, 22(5), 323-327.

Fjortoft, I. (2001). The natural environment as a playground for children: The impact of outdoorplay activities in pre-primary school children. Early Childhood Education Journal, 29(2), 111-117.

Gass, M. A. \& Priest, S. (2005). Effective leadership in adventure programming. Human Kinetics: Champaign, IL.

Godbey, G. (2009). Outdoor Recreation, Health, and Wellness: Understanding and Enhancing the Relationship. SSRN Electronic Journal, 09(21), 1-29.

Gollins, G. \& Walsh, V. (1976). An exploration of the Outward Bound process. Denver, Outward Bound Publications.

Gorsuch, R. L. (1997). Exploratory factor analysis: Its role in item analysis. Journal of Personality Assessment, 68(3), 532-560.

Gürbüz, S. \& Şahin, F. (2016). Sosyal bilimlerde araştırma yöntemleri: Felsefe, yöntem, analiz (3. Bask1). Ankara: Seçkin.

Hart, B. \& Risley, T. R. (1995). Meaningful differences in the everyday experience of young american children. Baltimore, Maryland: Paul H Brookes Publishing.

Handler, D. \& Epstein, A. S. (2010). Nature education in preschool. Highscope Extensions, 25(2), 1-7. Retrived on April 5, 2021 from http://membership.highscope.org/app/issues/144.pdf

Hopkins, D. \& Putnam, R. (1993). Personal growth through adventure. London: David Fulton.

Hu, L. \& Bentler, P. M. (1999). Cut off criteria for fit indexes in covariance structure analysis: Conventionalcriteria versus new alternatives. Structural Equation Modeling, 3, 424-453.

Huttenlocher, J., Hedges, L. V. \& Duncan, S. (1991). Categories andparticulars: Prototype effects in estimating spatial location. Psychological Review, 98, 352-376. 
Jencks, C. \& Phillips, M. (Eds.). (1998). The black white test scoregap. Washington, DC: The Brookings Institute.

Marsh, H. W., Hau, K. T., Artelt, C., Baumert, J. \& Peschar, J. L. (2006). OECD's Brief self-report measure of educational psychology's most useful affective constructs: cross-cultural, psychometric comparisons across 25 countries. International Journal of Testing, 6(4), 311-360.

Mittelstaedt, R. D. \& Jones, J. J. (2009). Outdoor Recreation SelfEfficacy: Scale Development. Reliability and Validity. Journal OfOutdoor Recreation. Education and Leadership, 1(1), 97-120.

Natriello, G., McDill, E. L. \& Pallas, A. M. (1990). Schooling disadvantaged children: Racing against catastrophe. New York: Teachers College Press

Hope, G. (2008) Thinking and learning through drawing in primary classrooms. London, Sage.

Hopkins, D. \& Putnam, R. (2012). Personal growth through adventure. Routledge: London.

Huizinga, J. (2017). Homo Ludens oyunun toplumsal işlevi üzerine bir deneme. İstanbul: Ayrıntı Yayınları.

Johns, G. (2010). Presenteeism in the workplace: a review and research agenda. Journal of Organizational Behavior, 31(4), 45-63.

Kalaycı, Ş. (2008). SPSS uygulamalı çok değişkenli istatistik teknikleri. Ankara: Asil Yayın Dağıtım.

Kalish, S. (1995). Your child's fitness: practical advice for parents. Champaign: Human Kinetics.

Karasar, N. (2012). Bilimsel araştırma yöntemi. Ankara: Nobel Yay.

Kline, R. B. (2011). Principles and practice of structural equation modeling. New York: The Guilford Press.

Korkmaz, E. (2009). Oyunu çocuk gelişimine etkisi ve çocuk oyun alanları tasarım kriterleri. Retrive on April 8, 2021 from http:// www.planlama.org/new/makaleler/oyunun-cocuk-gelisimineetkisive-cocuk-oyun-alanlari-tasarim-kriterleri.html

Linn, S. (2010). Commercialism in children's lives. In Worldwatch Institute: State of the world 2010: Transforming cultures from consumerism to sustainability (pp. 62-68). New York: W. W. Norton.

Louv, R. (2008). Last Child in the Woods: Saving Our Children from Nature Deficit Disorder. Chapel Hill: Algonquin Books.

Mackett, R. \& Paskins, J. (2008), Children's physical activity: The contribution of playing and walking, Children and Society, 22, 345-7. Doi: 10.1111/j.1099-0860.2007.00113.x

McInnes, K. \& Birdsey, N. (2013). Understanding play: The perceptions of children, adolescents, parents and teachers. In 2nd Global Conference: Making Sense of Play. Oxford, UK.

McKenzie, S. J. (1986). Teaching teachers. Roundtable Reports, 11(2), 9-10.

Miles, J. \& Priest, S. (1990). Adventure education. Venture: State College.

Miller, E. \& Kuhaneck, H. (2008). Children's perceptions of play experiences and the development of play preferences: A qualitative study. American Journal of Occupational Therapy, 62, 407-415.

Oğuzkan, Ş. \& Oral, G. (1997). Okulöncesi eğitimi. İstanbul: Milli Eğitim Basımevi.

Ouvry, M. (2003). Exercising muscles and minds: Outdoor play and the early years curriculum. London: National Children's Bureau.

Outdoor Training. (n.d.). Retrived on April 11, 2021 from http:// www.girlscouts-chicago.org/outdoortraining
Özdamar, K. (2004). Paket programlar ile istatistiksel veri analizi. Eskişehir: Kaan Kitabevi.

Pellegrini, A. \& Smith, P. (1993). School recess: implications for education and development. Review of Educational Research, 63, 51-67.

Patton, M. Q. (2005) Qualitative Research. Qualitative Research. Sage, Thousand Oaks, CA.

Perry, J. (2001). Outdoor play: Teaching strategies with young children. New York: Teachers College Press.

Pyle, R. M. (2002). Eden in a vacant lot: special places, species and kids in the neighborhood of life. In P. H. Kahn \& S. R. Kellert (Eds.), Children and nature: Psychological, sociological, and evolutionary investigations (pp. 305-327). Cambridge, MA: Massachusetts Institute of Technology Press.

Rivkin, M. (2000). The schoolyard habitat movement: What it is and why children need it. Early Childhood Education Journal, 25(1), 61-66.

Sanders, M. G. (2002). Community involvement in schools: Factors influencing its viability as a school reform strategy (working paper). Baltimore: Johns Hopkins University, Center for Research on the Education of Students Placed at Risk.

Scales, B. (1987). Play: The child's unseen curriculum. In P MonighanNourot, B Scales, J VanHoom \& M Almy (eds), Looking at children's play: A bridge between theory andpractice. New York: Teachers College Press, 89-115.

Schumann, S. \& Sibthorp, J. (2014). The development and scaling of the Teaching Outdoor Education Self-Efficacy Scale. Journal of Research in Outdoor Education, 12, 80-98. doi:10.7768/19485123.1217

Seçer, İ. (2015). Psikolojik test geliştirme ve uyarlama süreci SPSS ve LISREL uygulamaları. Ankara: Anı Yayıncılık.

Singer, D. \& Singer, J. (2000). Make-believe: games and activities for imaginative play. Washington, DC: Magination Press.

Stiehl, J. \& Parker, M. (2010). Outdoor education. In J. Lund \& D. Tannehill (Eds.), Standards- based physical education curriculum development (2nd ed., pp. 247-269). Boston, MA: Jones and Bartlett Publishers.

Süslü, K. N. E. (2014). Çocuk eğitiminde oyun dili. İstanbul: Hayykitap Yayınlar1

Tabachnick, B. G. \& Fidell, L. S. (2001). Using multivariate statistics (fourth edition). Boston: Ally And Bacon.

Tashakkori, A. \& Teddlie, C. (2003). Introduction to mixed method and mixed model studies in the social and behavioral sciences. In (Eds.). Plano Clark, V., \& Creswell, J. (2003). The mixed methods reader. Thousand Oaks, CA: Sage.

Tavşanc1l, E. (2019). Tutumların ölçülmesi ve SPSS ile veri analizi. Ankara: Nobel Yayıncılık.

Tezbaşaran, A. A. (1997). Likert tipi ölçek hazırlama kılavuzu. Türk Psikologlar Derneği, Ankara.

Tezci, E. (2016). Eğitimde ölçme ve değerlendirme. Ankara: Detay Yayıncilik.

Trawick-Smith, J. (1998). A qualitative analysis of meta-play in the preschool years. Early Childhood Research Quarterly, 13(3), 433-452.

Türkmen, U. (2010). Çocuğun bireysel toplumsal ve kültürel gelişiminde amatör müzik eğitiminin yeri problemleri ve çözüm önerileri. İlköğretim Online, 9(3), 1-13. 
Ulusal Sağlık İstatistikleri Merkezi. (2004). National Association for Sport and Physical Education.Moving into the future National standards for physical education: A guide to content and assessment. Reston, VA: Author.

Ulusal Spor ve Beden Eğitimi Derneği. (NASPE-National Association for Sport and Physical Education). (2010). Active start: a statement of physical activity guidelines for children from birth to age 5, 2nd Edition. AAHPERD Publications, Oxon Hill, Md. Retrived on May 15, 2021 from http://www. aahperd.org/naspe/ standards/nationalGuidelines/Active Start.cfm.

Vygotsky, L. S. (1978). Mind in society: The development of higher psychological processes. Cambridge, MA: Harvard University Press

Waite, S. (2011). Teaching and learning outside the classroom: personal values, alternative pedagogies and standards.
Education, 313(391), 65-82. DOI:10.1080/03004270 903206141

Wells, N. (2000). At home with nature: Effects of "greenness" on children's cognitive functioning. Environment and Behavior, 32(6), 775-795. doi: 10.1177/00139160021972793

White, J. (2011). Capturing the difference: The special nature of the outdoors. In J. White (Ed.), Outdoor provision in the early years (pp.45-56). London, England: Sage.

Worthington, R. \& Whittaker, T. (2006). Scale development research: A content analysis andrecommendations for best practices. Counseling Psychologist, 34, 806-838. doi:10.1177/0011000006288127

Yaşlıoğlu, M. M. (2017). Sosyal bilimlerde faktör analizi ve geçerlilik: keşfedici ve doğrulayıcı faktör analizlerinin kullanılması. Istanbul University Journal of the School of Business, 46, Special Issue, 74-85. 